\title{
Effect of Various Surface Sterilant on Contamination and Callus Regeneration of Ashoka (Saraca asoca Roxb. De Wilde) from Leaf Segment Explant
}

\author{
Sandeep Rout* and Neelam Khare \\ College of Forestry, Sam Higginbottom University of Agriculture Technology and \\ Sciences, Allahabad-211007, Uttar Pradesh, India \\ *Corresponding Author
}

\section{A B S T R A C T}

\section{Keywords}

Callus,

Contamination,

Regeneration,

Sterilant

Article Info

Accepted:

15 June 2018

Available Online:

10 July 2018
The present experiment was conducted to find out the most suitable surface sterilant and timing for controlling contamination in the leaf segment explants of Ashoka (Saraca asoca Roxb. De Wilde) using MS as basal medium with BAP $(2.0 \mathrm{mg} / \mathrm{l})$ and NAA $(0.5 \mathrm{mg} / \mathrm{l})$. Among the various sterilants and timing the explants sterilized with $0.1 \% \mathrm{HgCl}_{2}$ for $15 \mathrm{~min}+1 \% \mathrm{NaOCl}$ for $2 \mathrm{~min}$ significantly reduced the percentage of fungal contamination $(6.67 \%)$, maximum aseptic culture (93.33\%). Callus percentage maximum was recorded in $\mathrm{T}_{19}(0.1 \%$ $\mathrm{HgCl}_{2}$ for $15 \mathrm{~min}+1 \% \mathrm{NaOCl}$ for $\left.2 \mathrm{~min}\right)(93.33 \%)$ and callus spread $(2.33 \times 1.00$ $\mathrm{cm}$ ) was recorded in similar treatment. In vitro propagation of this high valued medicinal tree is of great importance for the mass supply of disease free planting materials.

\section{Introduction}

Trees constitute an important component of forests. It is an admitted fact that tree is the invariable resources for providing food, fodder, timber and medicines items of daily life. So there is natural and anthropogenic pressure on these natural resources. Tree has been the treasure house of a wide range of valuable medicinal and aromatic plants on account of vast diversity in climatic condition. Most of them used in Ayurvedic, Unani, Siddha, Homeopathic, Allopathic and other alternative medicinal practices such as folk medicine, household remedies, naturopathy.
The WHO has estimated the present demand for medicinal plants is approximately US \$14 billion per year (Sharma, 2004). With time deforestation for cultivation of food, fodder, shelter and pasture diversion for the developmental purpose and removal of valuable trees affected the forest resources adversely at a greater rate making them threatened.

Ashoka (Saraca asoca Roxb.De Wilde) syn. Saraca indica belongs to family Fabaceae is a medium sized evergreen tree growing up to $9 \mathrm{~m}$ high, with numerous spreading and drooping glabrous branches. Leaves are 
pinnate, $30-60 \mathrm{~cm}$ long having $2-3$ pairs of lanceolate leaflets. Flowers are orange or orange yellow, arranged in dense corymbs and very fragrant. Fruits are flat black pods, leathery and compressed with 4-8 seed/pod. Seeds are ellipsoid oblong and compressed, The bark is dark brown to grey or black with a warty surface. The thickness varies from $5 \mathrm{~mm}$ to $10 \mathrm{~mm}$. The tree is found almost throughout India, except North-Western India, Up to $750 \mathrm{~m}$. It is also found in the Andaman Islands.

Saraca asoca posses varied medicinal uses. The bark is useful in dyspepsia, fever, burning sensation, ulcers, leucorrhoea and pimples. The leaf juice mixed with cumin seeds are used for treating stomachalagia. The flowers are considered to be uterine tonic and dysentery. The well known Ayurvedic preparations are "Ashokarishta" is prescribed in leucorrhoea and other diseases of female (Nudrat, et al. 2005). Producing commercially valuable Ashoka with high levels of medicinal properties requires Saraca asoca trees to be a minimum of 15 years old the age at which they will be harvested Saraca asoca is expensive compared to other types of woods, therefore to maximize the profit of bark is harvested by removing from the tree.

In vitro propagation of tree species offers a rapid means of producing clonal planting stock for afforestation, woody biomass production and conservation of elite and rare germplasm. The technique has great potential for rapid and large-scale multiplication of true to type planting material (Pierik, 1989). The desire of every researcher in tissue culture studies is to eliminate or prevent contamination, but unfortunately contamination cannot be eliminated totally but can be managed to reduce both frequency and occurrence, this can be achieved by surface sterilization (Barpanda et al. 2017). Surface sterilization is effective and cheap for getting contamination free culture. Hence, the present investigation was undertaken to find out the effect of various surface sterilant on contamination and callus regeneration of Ashoka (Saraca asoca Roxb. De Wilde) from Leaf segment explants.

\section{Materials and Methods}

The investigation was carried out at the Biotechnology-cum- Tissue Culture Center, OUAT, Bhubaneswar. The chemicals used for the present study were analytical reagents of excel R grade of Merck (India), Qualigen fine Chemicals, and Himedia Laboratories Ltd. (India). Auxins, Cytokinins, Myo-inositol and Fe-EDTA were from Sigma (USA) and Agar from Himedia Lab Ltd (India). For the preparation of MS culture medium (Murashige and Skoog, 1962) required quantities of macronutrients, micronutrients, Fe-EDTA, vitamins and plant bio regulators were taken from the stock solution and required quantity of sucrose dissolved in water was added fresh to the medium. The $\mathrm{pH}$ of the solution was adjusted to $5.7 \pm 0.1$ using $0.1 \mathrm{~N} \mathrm{NaOH}$ or 0.1 $\mathrm{N} \mathrm{HCl}$. The volume was made up to 1 liter with distilled water. Agar $(0.8 \%$ w/v) was added to the medium boiled and poured to the culture tubes and plugged with non-absorbent cotton. Plugged culture tubes containing culture medium were autoclaved for the 20 minutes at $121^{\circ} \mathrm{C}$ and 15 Psi pressure. The autoclaved medium was kept in a laminar air flow bench for cooling. All the glassware were dipped in the detergent solution overnight and washed under running tap water. They were rinsed with distilled water and then dried in an oven for $2 \mathrm{hrs}$ at $150^{\circ} \mathrm{C}$. Forceps, petridishes and scaples were thoroughly cleaned with isopropanol and wrapped with paper and kept in a clean sterilized in the autoclave at $15 \mathrm{psi}$ and $121{ }^{\circ} \mathrm{C}$ for 20 minutes. The working chamber of laminar air flow cabinet was wiped with isopropanol. Filtered air (80-100 $\mathrm{cft} / \mathrm{min}$ ) to ensure that particles do not settle in working area was blown for $5 \mathrm{~min}$. The sterilized materials to be used (except living 
tissue) were kept made the chamber and exposed to UV light for 30 minutes. The sterilized explants were inoculated in culture tubes containing the media. Cut ends of explants will be kept in such a way so as to have maximum contact with the medium. All the aseptic manipulations such as surface disinfection of explants, preparation and inoculation of explants and subsequent culturing were carried out in the laminar air flow cabinet. The working table of laminar airflow cabinet and spirit lamp was sterilized by swabbing with absolute alcohol. All the required materials like media, spirit lamp, matchbox, glassware etc., were transferred on to the clean laminar airflow. The UV light will switch on for half an hour to achieve aseptic environment inside the cabinet.

Explant was collected from the plus tree identified in Bhubaneswar (Khurda) Odisha. The explants were washed thoroughly in running tap water for 30 minutes, followed by tween 20 for $15 \mathrm{~min}$. Further aseptic surface sterilization was carried out with $2 \%$ bavistin with constant stirring which was then rinsed out after 30 min with sterile distilled water for three times. The sterilized leaf explants were then prepared by into individuals, subjected to further surface sterilant solution as per different treatment for different timing and a control in the laminar airflow. These sterilized explants were then cultured on Murashige and Skoog (1962) medium supplemented with plant bioregulators BAP $(2.0 \mathrm{mg} / 1)$ and NAA $(0.5 \mathrm{mg} / 1)$ with $8 \%(\mathrm{w} / \mathrm{v})$ agar, $30 \%(\mathrm{w} / \mathrm{v})$ sucrose replicated thrice. The observation of the following parameters was recorded after 60 days after inoculation (DAI) on Fungal \%, Bacterial $\%$ contamination, death $\%$, survival $\%$ and aseptic \%. For callusing study, following observation on days to callusing, $\%$ of callusing, callus spread, colour of the callus and nature of callus recorded at 60 DAI. After inoculation, the cultures were kept, at $25 \pm 2^{0} \mathrm{C}$ in an air conditioned room with a 16 hours photo period (3000-3200 lux) light intensity and $80 \%$ relatively humidity. All of the experiments were replicated thrice and 10 culture tubes per replication in each treatment were taken. The raw data obtained during the experimental observations were subjected to completely randomized design (Gomez and Gomez, 1984). The significance and nonsignificance of the treatment effect were judged with the help of ' $F$ ' variance ratio test. Calculated ' $F$ ' value was compared with the table value of ' $F$ ' at $5 \%$ level of significance. The data were transferred from where ever required before suitability of Analysis of Variance (ANOVA) analyzed in statistical package SAS version 7.0.

\section{Results and Discussion}

The results of the experiment on timing of sterilant in leaf segment explants(Table.1) revealed that the leaf segment explants surface sterilised by $0.1 \% \mathrm{HgCl}_{2}$ for 15 minutes+ $1 \%$ $\mathrm{NaOCl}$ for $2 \mathrm{Min}$. significantly reduced the percentage of fungal infection $(6.67 \%)$ and the data stood at par with the treatment $\mathrm{T}_{12}(0.1 \%$ $\mathrm{HgCl}_{2}$ for 15 minutes. Significantly maximum fungal infection $100 \%$ was recorded in control i.e. $\mathrm{T}_{1}$ and $\mathrm{T}_{13}(1 \% \mathrm{NaOCl}$ for $5 \mathrm{Min})$.

The result of bacterial infection showed nonsignificant results. In treatment $\mathrm{T}_{1}$ (control) led condition there is no bacterial infection as all the explants have contaminated due to fungal infection. However lower percentage of bacterial infection (3.33) was recorded in treatment $\mathrm{T}_{9}\left(0.1 \% \mathrm{HgCl}_{2}\right.$ for 8 minutes $), \mathrm{T}_{10}$ $\left(0.1 \% \mathrm{HgCl}_{2}\right.$ for 9 minutes).

Aseptic culture was significantly higher $(93.33 \%)$ with $\mathrm{T}_{19}\left(0.1 \% \mathrm{HgCl}_{2}\right.$ for 15 minutes $+1 \% \mathrm{NaOCl}$ for $2 \mathrm{Min}$ ) and the data stood par with $\mathrm{T}_{12}\left(0.1 \% \mathrm{HgCl}_{2}\right.$ for 15 minutes $)$. There was no aseptic culture as all the explants have contamination due to fungal infection in treatment $\mathrm{T}_{1}$ (control) and $\mathrm{T}_{13}$. 
Table.1 Effect of surface sterilant and duration of time on leaf segment explants $\quad$ [MS+2.0 mg/l BAP+0.5mg/l NAA (60DAI)]

\begin{tabular}{|c|c|c|c|c|c|}
\hline Treatment & Fungal \% & Bacterial\% & Death \% & Aseptic \% & Survival \% \\
\hline $\mathbf{T}_{1}$ (Tap water) (Control) & $100.00(90.00)$ & $0.00(0.00)$ & $0.00(0.00)$ & $0.00(0.00)$ & $0.00(0.00)$ \\
\hline $\mathrm{T}_{2}\left(0.1 \% \mathrm{HgCl}_{2} 1 \mathrm{~min}\right)$ & $90.00(71.56)$ & $0.00(0.00)$ & $0.00(0.00)$ & $10.00(18.44)$ & $10.00(18.44)$ \\
\hline $\mathrm{T}_{3}\left(0.1 \% \mathrm{HgCl}_{2} 2 \mathrm{~min}\right)$ & $80.00(63.44)$ & $0.00(0.00)$ & $0.00(0.00)$ & $20.00(26.56)$ & $20.00(26.56)$ \\
\hline $\mathrm{T}_{4}\left(0.1 \% \mathrm{HgCl}_{2} 3 \mathrm{~min}\right)$ & $76.67(61.10)$ & $0.00(0.00)$ & $0.00(0.00)$ & $23.33(28.86)$ & $23.33(28.86)$ \\
\hline $\mathrm{T}_{5}\left(0.1 \% \mathrm{HgCl}_{2} 4 \mathrm{~min}\right)$ & $76.67(61.10)$ & $0.00(0.00)$ & $0.00(0.00)$ & $23.33(28.86)$ & $23.33(28.86)$ \\
\hline $\mathrm{T}_{6}\left(0.1 \% \mathrm{HgCl}_{2} 5 \mathrm{~min}\right)$ & $76.67(61.10)$ & $0.00(0.00)$ & $0.00(0.00)$ & 23.3328.86) & 23.3328.86) \\
\hline $\mathrm{T}_{7}\left(0.1 \% \mathrm{HgCl}_{2} 6 \mathrm{~min}\right)$ & $66.67(54.78)$ & $0.00(0.00)$ & $0.00(0.00)$ & $33.33(35.24)$ & $33.33(35.24)$ \\
\hline $\mathrm{T}_{8}\left(0.1 \% \mathrm{HgCl}_{2} 7 \mathrm{~min}\right)$ & $63.33(52.71)$ & $0.00(0.00)$ & $0.00(0.00)$ & $36.67(37.26)$ & $36.67(37.26)$ \\
\hline $\mathrm{T}_{9}\left(0.1 \% \mathrm{HgCl}_{2} 8 \mathrm{~min}\right)$ & $36.67(37.26)$ & $3.33(10.47)$ & $0.00(0.00)$ & $60.00(50.77)$ & $60.00(50.77)$ \\
\hline $\mathrm{T}_{10}\left(0.1 \% \mathrm{HgCl}_{2} 9 \mathrm{~min}\right)$ & $33.33(35.24)$ & $3.33(10.47)$ & $0.00(0.00)$ & $63.33(52.71)$ & $63.33(52.71)$ \\
\hline $\mathrm{T}_{11}\left(0.1 \% \mathrm{HgCl}_{2} 10 \mathrm{~min}\right)$ & $30.00(33.21)$ & $10.00(18.44)$ & $0.00(0.00)$ & $70.00(56.79)$ & $70.00(56.79)$ \\
\hline $\mathrm{T}_{12}\left(0.1 \% \mathrm{HgCl}_{2} 15 \mathrm{~min}\right)$ & $10.00(18.44)$ & $10.00(18.44)$ & $0.00(0.00)$ & $80.00(63.44)$ & $80.00(63.44)$ \\
\hline $\mathrm{T}_{13}(1 \% \mathrm{NaOCl} 5 \mathrm{~min})$ & $100.00(90.00)$ & $0.00(0.00)$ & $0.00(0.00)$ & $0.00(0.00)$ & $0.00(0.00)$ \\
\hline $\mathrm{T}_{14}(1 \% \mathrm{NaOCl} 10 \mathrm{~min})$ & $90.00(71.56)$ & $0.00(0.00)$ & $0.00(0.00)$ & $10.00(18.44)$ & $10.00(18.44)$ \\
\hline $\mathrm{T}_{15}(1 \% \mathrm{NaOCl} 15 \mathrm{~min})$ & $80.00(63.44)$ & $0.00(0.00)$ & $0.00(0.00)$ & $20.00(26.56)$ & $20.00(26.56)$ \\
\hline$T_{16}(70 \%$ Propanol $5 \mathrm{~min})$ & $90.00(71.56)$ & $0.00(0.00)$ & $0.00(0.00)$ & $10.00(18.44)$ & $10.00(18.44)$ \\
\hline$T_{17}(70 \%$ Propanol $10 \mathrm{~min})$ & $90.00(71.56)$ & $0.00(0.00)$ & $0.00(0.00)$ & $10.00(18.44)$ & $10.00(18.44)$ \\
\hline$T_{18}(70 \%$ Propanol $15 \mathrm{~min})$ & $86.67(68.57)$ & $0.00(0.00)$ & $0.00(0.00)$ & $13.33(21.39)$ & $13.33(21.39)$ \\
\hline $\begin{array}{l}\mathrm{T}_{19}\left(0.1 \% \mathrm{HgCl}_{2} 15 \mathrm{~min}+1 \%\right. \\
\mathrm{NaOCl} 2 \mathrm{~min})\end{array}$ & $6.67(14.94)$ & $0.00(0.00)$ & $0.00(0.00)$ & $93.33(75 . .00)$ & $93.33(75 . .00)$ \\
\hline $\mathrm{SE}(\mathrm{m}) \pm$ & 2.61 & - & - & 7.12 & 7.12 \\
\hline $\mathrm{CD}$ at $5 \%$ & 7.39 & - & - & 20.00 & 20.00 \\
\hline
\end{tabular}

$* *$ Value in parenthesis is arc sine value 
Table.2 Impact of timing of sterilant on callus initiation and development of the leaf segments explants [MS+2.0 mg/l BAP+0.5mg /1 NAA (60DAI)]

\begin{tabular}{|c|c|c|c|c|c|c|}
\hline \multirow[t]{2}{*}{ Treatments } & \multirow{2}{*}{$\begin{array}{l}\text { Days to } \\
\text { Callusing }\end{array}$} & \multirow{2}{*}{$\begin{array}{c}\text { Colour of } \\
\text { Callus }\end{array}$} & \multirow[t]{2}{*}{ Nature of the Callus } & \multirow[t]{2}{*}{ Callusing \% } & \multicolumn{2}{|c|}{ Callus Spread (cm) } \\
\hline & & & & & $\mathbf{L}$ & B \\
\hline $\mathbf{T}_{1}$ (Tap water)(Control) & 0.00 & - & - & $0.00(0.00)$ & 0.00 & 0.00 \\
\hline $\mathrm{T}_{2}\left(0.1 \% \mathrm{HgCl}_{2} 1 \mathrm{~min}\right)$ & 37.67 & Off white & Fragile & $10.00(18.44)$ & 0.25 & 0.47 \\
\hline $\mathrm{T}_{3}\left(0.1 \% \mathrm{HgCl}_{2} 2 \mathrm{~min}\right)$ & 38.33 & Off white & Fragile & $20.00(26.56)$ & 0.25 & 0.53 \\
\hline $\mathrm{T}_{4}\left(0.1 \% \mathrm{HgCl}_{2} 3 \mathrm{~min}\right)$ & 38.00 & Off white & Fragile & $23.33(28.86)$ & 0.33 & 0.50 \\
\hline $\mathrm{T}_{5}\left(0.1 \% \mathrm{HgCl}_{2} 4 \mathrm{~min}\right)$ & 38.00 & Off white & Fragile & $23.33(28.86)$ & 0.50 & 0.50 \\
\hline $\mathrm{T}_{6}\left(0.1 \% \mathrm{HgCl}_{2} 5 \mathrm{~min}\right)$ & 38.00 & Off white & Fragile & 23.3328.86) & 0.57 & 0.47 \\
\hline $\mathrm{T}_{7}\left(0.1 \% \mathrm{HgCl}_{2} 6 \mathrm{~min}\right)$ & 38.00 & Off white & Fragile & $33.33(35.24)$ & 0.68 & 0.55 \\
\hline $\mathrm{T}_{8}\left(0.1 \% \mathrm{HgCl}_{2} \mathbf{7 m i n}\right)$ & 42.67 & Off white & Fragile & $36.67(37.26)$ & 0.58 & 0.70 \\
\hline $\mathrm{T}_{9}\left(0.1 \% \mathrm{HgCl}_{2} 8 \mathrm{~min}\right)$ & 43.00 & Off white & Fragile & $60.00(50.77)$ & 0.72 & 0.85 \\
\hline $\mathrm{T}_{10}\left(0.1 \% \mathrm{HgCl}_{2} 9 \mathrm{~min}\right)$ & 46.00 & Off white & Fragile & $63.33(52.71)$ & 2.92 & 1.00 \\
\hline $\mathrm{T}_{11}\left(0.1 \% \mathrm{HgCl}_{2} 10 \mathrm{~min}\right)$ & 46.00 & Off white & Fragile & $70.00(56.79)$ & 1.65 & 0.95 \\
\hline $\mathrm{T}_{12}\left(0.1 \% \mathrm{HgCl}_{2} 15 \mathrm{~min}\right)$ & 47.00 & Off white & Slightly fragile & $80.00(63.44)$ & 1.83 & 1.00 \\
\hline $\mathrm{T}_{13}(1 \% \mathrm{NaOCl} 5 \mathrm{~min})$ & 0.00 & Off white & Fragile & $0.00(0.00)$ & 0.00 & 0.00 \\
\hline $\mathrm{T}_{14}(1 \% \mathrm{NaOCl} 10 \mathrm{~min})$ & 48.67 & Off white & Fragile & $10.00(18.44)$ & 0.32 & 0.48 \\
\hline$T_{15}(1 \%$ NaOCl $15 \mathrm{~min})$ & 49.33 & Off white & Fragile & $20.00(26.56)$ & 0.27 & 0.50 \\
\hline$T_{16}(70 \%$ Propanol $5 \mathrm{~min})$ & 40.00 & Off white & Fragile & $10.00(18.44)$ & 0.37 & 0.48 \\
\hline $\begin{array}{l}T_{17}(70 \% \text { Propanol } 10 \\
\text { min) }\end{array}$ & 41.33 & Off white & Fragile & $10.00(18.44)$ & 1.45 & 0.70 \\
\hline $\begin{array}{l}\mathbf{T}_{18}(\mathbf{7 0} \% \text { Propanol } 15 \\
\text { min) }\end{array}$ & 42.00 & Off white & Fragile & $13.33(21.39)$ & 1.47 & 0.75 \\
\hline $\begin{array}{l}\mathrm{T}_{19}\left(0.1 \% \mathrm{HgCl}_{2} 15 \mathrm{~min}+\right. \\
1 \% \mathrm{NaOCl} 2 \mathrm{~min})\end{array}$ & 47.00 & Off white & Slightly fragile & $93.33(75 . .00)$ & 2.33 & 1.00 \\
\hline $\mathrm{SE}(\mathrm{m}) \pm$ & 0.87 & - & - & 7.12 & - & - \\
\hline $\mathrm{CD}$ at $5 \%$ & 2.48 & - & - & 20.00 & - & - \\
\hline
\end{tabular}

**Value in parenthesis is arc sine value 
Percentage of the death of the explants was significantly low (0.00) in all treatments. There is no death of the explants due to surface sterilants in treatments. The explants surface sterilised with by $0.1 \% \mathrm{HgCl}_{2}$ for 15 minutes $+1 \% \mathrm{NaOCl}$ for $2 \mathrm{Min}$ recorded significantly higher percentage of survival (93.33\%) followed by $\mathrm{T}_{12}\left(0.1 \% \mathrm{HgCl}_{2}\right.$ for 15 minutes) $(80.00 \%)$. The results are in close conformity with those of Beura et al. (2016), Ghochhayat and Beura et al. (2017). However mercuric chloride gave better results or in combination when compared to $\mathrm{NaOCl}$ and $70 \%$ Propanol. $\mathrm{NaOCl}_{2}$ and $70 \%$ Propanol alone did not found acceptable sterilants even on increasing time similar findings are also reported in Asparagus densiflorus (Amutha et al. 2008). The sterilizing agent should be used for an appropriate duration to control contamination. However $\mathrm{HgCl}_{2}$ which has mainly antibacterial action was more efficient and should be used for decontamination percentage ( Rihan , 2012)

The data presented in table 2 . revealed that explants treated with $0.1 \% \quad \mathrm{HgCl}_{2}$ for 1 minute significantly reduced the days to callus initiation(37.67) remaining at par with $\mathrm{T}_{4}\left(0.1 \% \mathrm{HgCl}_{2}\right.$ for 3 minutes $), \mathrm{T}_{5}(0.1 \%$ $\mathrm{HgCl}_{2}$ for 4 minutes $), \mathrm{T}_{6}\left(0.1 \% \mathrm{HgCl}_{2}\right.$ for 5 minutes) and $\mathrm{T}_{7}\left(0.1 \% \mathrm{HgCl}_{2}\right.$ for 6 minutes $)$ and callusing percentage were significantly higher $(93.33 \%)$ in $\mathrm{T}_{19}\left(0.1 \% \mathrm{HgCl}_{2}\right.$ for 15 minutes $+1 \% \mathrm{NaOCl}$ for $2 \mathrm{Min}$ ) remaining at par with $\mathrm{T}_{12}\left(0.1 \% \mathrm{HgCl}_{2}\right.$ for 15 minutes $)$. The callus spread was higher $(2.33 \times 1.00)$ in $\mathrm{T}_{19}\left(0.1 \% \mathrm{HgCl}_{2}\right.$ for 15 minutes $+1 \% \mathrm{NaOCl}_{2}$ for $2 \mathrm{Min})$. Considering all the characters of the impact of sterilant, leaf segments surface sterilized with $0.1 \% \mathrm{HgCl}_{2}$ for 15 minutes $+1 \% \mathrm{NaOCl}_{2}$ for $2 \mathrm{Min}$ was found to be best for Ashoka (Saraca asoca Roxb. De Wilde). The results are in alignment with the findings of Patnaik and Beura, (2008); Gochhayat et al. (2017).
It was concluded that for in vitro propagation of Ashoka (Saraca asoca Roxb. De Wilde) leaf segment explants sterilized with $0.1 \%$ $\mathrm{HgCl}_{2}$ for $15 \mathrm{~min}+1 \% \mathrm{NaOCl}$ for $2 \mathrm{~min}$ is more effective for getting maximum aseptic culture, survival of explants along with maximum callus growth and found to be most effective for the purpose of mass multiplication with-in short period of time.

\section{Acknowledgment}

The authors acknowledge the financial support provided by the DST - Inspire (Dept. of Science and Technology), the President and Govt. of India for encouraging students like me via "DST-INSPIRE FELLOWSHIP".

\section{References}

Amutha, R, Jawahar, M. and Paul S.R.(2008).Plant regeneration and in vitro flowering from shoot tip of Basillicum Polystachyon L. MoenchAn important medicinal plants. Journal of Agriculture technology. 4(2):117-123.

Barpanda, S., Beura, S., Rout, S., and Jagadev, P.N. (2017).Studies on in vitro regeneration of Sandalwood (Santalum album Linn) from leaf disc explants. Journal of Pharmacognosy and Phytochemistry. 6(6):892-896.

Beura, S., Mohanty, P., Rout, S. and Beura, R.(2016). In vitro clonal propagation of an ornamental garden plant Bauhinia galpinni. Journal of tropical Forestry. 32 (2):71-82.

Gochhayat, A.A., Beura, S. and Subudhi, E. (2017). Studies on the effect of surface sterilization time and plant bio regulators on in vitro regeneration of bulb scale explants of Hybrid Lilium $\mathrm{Cv}$ Sorbonne. International Journal of Advanced Biological Research. 7(4):641-645. 
Gochhayat, A.A., Beura, S. and Subudhi, E.(2017).Effect of surface sterilization time and plant bioregulators for callus formation in hybrid Lilium $\mathrm{Cv}$. Tresor. Biosciences Biotechnology research Asia.14 (2):709-713.

Gomez, K.A. and Gomez, A.A. (1984). Statistical procedures for agricultural research 3rd edn, John Wiley \& Sons, Singapore.680 p.

Murashige, T. and Skoog, F.A.(1962) revised medium for rapid growth and bioassays with tobacco cultures. Physiologia Plantarum. 15(3):473497.

Nudrat, S. Z. and Mukundan, U. (2005). Medicinal and Aromatic plants of India,Part I by I A Khan and A Khanum (Eds), Ukaaz Publication ,Hydrabad.p-35.
Pattnaik, S. and Beura, S. (2008). High frequency in vitro callusing of Gerbera (G. jamesonii Bolus).The Orissa Journal of Horticulture. 36(1):108115.

Pierik, P.L.M. (1989) In vitro culture of higher plants. Martinus Nijhoff Publishers, Dordrecht, Netherlands.

Rihan, H.Z, Mohammed, A., Fadil, A. and Michael, P. F. (2012). The effect of using PPM (plant preservative mixture) on the development of cauliflower micro shoots and the quality of artificial seed produced. Scientia Horticulturae. 141: 47-52.

Sharma, A.B. (2004) Global Medicinal Plants Demand May Touch \$5 Trillion By 2050. Indian Express Monday March 29.

\section{How to cite this article:}

Sandeep Rout and Neelam Khare. 2018. Effect of Various Surface Sterilant on Contamination and Callus Regeneration of Ashoka (Saraca asoca Roxb. De Wilde) from Leaf Segment Explant. Int.J.Curr.Microbiol.App.Sci. 7(07): 2027-2033.

doi: https://doi.org/10.20546/ijcmas.2018.707.239 